\title{
Interview
}

\section{Reflecting on CLIL innovation. An interview with Do Coyle and Elisabet Pladevall}

\author{
Inma Piquer Vives ${ }^{1}$ and Neus Lorenzo Galés ${ }^{2}$ \\ ${ }^{1}$ Universitat de Barcelona, Blanquerna Universitat Ramon Llull \& Departament \\ d'Ensenyament, Generalitat de Catalunya, Barcelona, Spain \\ ${ }^{2}$ Departament d'Ensenyament, Generalitat de Catalunya, Barcelona, Spain
}

Text received 17 December, 2014; final version 23 February 2015

DOI:http://dx.doi.org/10.5565/rev/jtl3.610

\begin{abstract}
Las autoras reflexionan sobre el papel del AICLE (CLIL) en la experimentación pedagógica, la formación docente y la investigación universitaria, a partir de las conversaciones mantenidas con las profesoras Do Coyle (Universidad de Aberdeen, Escocia) y Elisabet Pladevall (Universitat Autònoma de Barcelona, Cataluña), en el marco del Máster Oficial en Estudios Ingleses Avanzados de la Universitat Autònoma de Barcelona (enero 2014). Realizan una breve pero significativa perspectiva de las necesidades en el contexto de los estudios universitarios y ponen de manifiesto la urgencia de plantear una revisión del CLIL en la era digital y plurilingüe, y un enfoque de intercambio transversal y transmedia en los multi-escenarios universitarios de educación.
\end{abstract}

\begin{abstract}
The authors reflect on the role of CLIL in experimental teaching, teacher education and university research, from discussions with Prof. Do Coyle (University of Aberdeen, Scotland) and Dr. Elisabet Pladevall (Universitat Autònoma de Barcelona, Catalonia), in the framework of the Masters in Advanced English Studies at the Universitat Autònoma de Barcelona (January 2014). They give a brief but significant outlook on needs in the context of university studies and highlight the urgency of conducting a review of CLIL for the plurilingual Digital Age, as well of focusing on cross-curricular and transmedia exchanges in the multiple scenarios of university education.

Les autores reflexionen sobre el paper de l'AICLE (CLIL) en l'experimentació pedagògica, la formació docent i la investigació universitària, a partir de les converses mantingudes amb les professores Do Coyle (Universitat d'Aberdeen, Escòcia) i Elisabet Pladevall (Universitat Autònoma de Barcelona, Catalunya), en el marc del Màster Oficial en Estudis Anglesos Avançats de la Universitat Autònoma de Barcelona (gener de 2014). Realitzen una breu però significativa perspectiva de les necessitats en el context dels estudis universitaris i posen de manifest la urgència de plantejar una revisió del CLIL a l'era digital i plurilingüe, i un enfocament d'intercanvi transversal i transmèdia en els multi-escenaris universitaris de educació.
\end{abstract}

\section{Introduction}

Content and Language Integrated Learning (CLIL) has become a basis for education research, teacher training and university collaboration all over the world. Now that higher education is in the process of evolving towards a more complex and internationalised educational experience, CLIL reveals itself to be one of the best approaches for collaboration, reflection, 
and action-research in university education. "When we speak of higher education, we can no longer limit ourselves to traditional notions of academically oriented education" (Gallon \& Lorenzo, 2014, p. 127). We need to include combined visions of formal, non-formal and professional interests from students, teachers, non-academic experts and all of society involved in the educational process.

In January 2014, Professor Do Coyle of the University of Aberdeen, Scotland, presented a lecture to Masters students in Advanced English Studies at the Faculty of English Philology (Universitat Autònoma de Barcelona). The attendees of the lecture were mostly primary and secondary teachers doing their postgraduate studies in Literacies (Learning and Linguistic fields) and Educational Linguistics. External experts on CLIL, Neus Lorenzo and Inma Piquer, had the opportunity to exchange views and information with participants at all levels (students, teachers, trainers and international experts) thanks to their common interest. CLIL has become a pole of attraction for practice, training and research, at both school and university levels.

In the past decades, a significant amount of research on foreign language teaching in the Catalonian context has focussed on the innovative measures that Catalan education has taken in the use of CLIL based teaching in plurilingual environments in areas such as:

- Enlarging the period of foreign language learning at school;

- Introducing foreign language learning at an earlier age;

- Embedding social and cultural aspects of language learning in the teaching process;

- Adopting oral and communicative teaching approaches.

Thanks to these innovations, Catalan university studies in the field of foreign language teaching have developed richer teacher training programmes and gained theoretical depth. Prof. Coyle's presence at the Masters conference, organised by Dr. Elisabet Pladevall, was an example of how university teacher training and practice, both at schools and universities, now offer increased opportunities for cross-curricular debate at international levels. Evolutions in learning theory, school practice experience and legislation have blended to facilitate the fast spread of foreign language learning school programmes in recent years (Lorenzo \& Piquer, 2014).

In the Catalan context, where plurilingualism and immersion approaches at school are deeply embedded, CLIL studies are easily integrated, because their principles are similar to those of Catalan immersion and content teaching (Marsh, 1994). Foreign language experts from the Department of Education in Catalonia, universities, institutions and schools share 
common aims for promoting innovative methodologies within their classes, and continuously upgrading their knowledge and experience by inviting national and international experts for a specific purposed.

The authors of this article had the pleasure of spending time with Prof. Coyle and her host Dr. Elisabet Pladevall, reflecting on the role of CLIL in higher education, action-research and teacher training. In our interview with Dr. Pladevall, from the Department of English and German (UAB), she stressed the need for disseminating not only the content of the CLIL conference, but also the organizational strategy behind it.

\section{Interview}

The authors: What is the added value of a meeting space for professors, university students, members of the Department of Education and international colleagues, such as the one you have organized?

Elisabet Pladevall: Inviting people from different backgrounds at the seminars offered by Professor Do Coyle matches with the principle of promoting relationships between students and teachers, one of the research areas of our guest. That is why we have proposed this lecture, these interviews and a round table seminar, to promote the participation of the audience. Professor Coyle has offered open talks to welcome students, teachers and experts. We truly believe this networking approach is the future of teacher training, for initial studies as well as in-service training.

The authors: Can you describe this networking organization with a specific example?

Elisabet Pladevall: I think this conference is a good example of joined synergies. On January the 10th (2014) Anna Vallbona, who is a student of our faculty of English Philology and a professor at the Universitat de Vic, was doing the defense of her doctoral thesis. It is part of a research project funded by the Ministry of Education and it deals with CLIL in primary schools in Catalonia. The title is very explicit: 'L2 Competence of Young Language Learners in Science and Arts and Crafts Instruction CLIL and EFL Contexts. A Longitudinal Study'. We were able to invite professor Do Coyle as a member of the jury, and we really wanted to maximize the impact of her visit. 
Professor Do Coyle is now the director of the School of Education which provides degree level Initial Teacher Education at the University of Aberdeen (Scotland) and she accepted to conduct a series of seminars for students and teachers in the Department of English and Germanic Philology, mainly for the UAB Master students, but also for undergraduate and graduate attendees of the Faculty of Education Sciences in our University, the departments of Education and English at the University of Barcelona and teachers from the University of Vic. The invitation was extended to experts from the Servei de Llengües Estrangeres in the Catalan Departament d'Educació and other researchers, with the intention of broadening the impact and the benefits of this collaboration. The result is what we are experiencing today.

The authors: What is the role of CLIL in the current multilingual European Union proposal?

Do Coyle: At the moment, in terms of plurilingual education, European policy is essentially driving a holistic view. So, education is not only about developing one's first language, but all the other languages that any individual is able to use. When we stand back and look at results obtained in countries which have put a lot of emphasis only on developing literacy in the first language, results show that it simply hasn't impacted across the curriculum and achieved its full potential. I think exploring the literacies pathways from a broader perspective provides us with a good way of looking at how children learn, and CLIL, because of its nature with languages and learning, to me is a space we can use to examine coherence in a different way.

At this moment in time, CLIL has a very important role to play in enabling educators to reconceptualise parts of the curriculum and the way that we deliver it in our schools. I see it not only as an enabler to re-look at the way that we deal with language learning, but more as a holistic view of what we do with language use and languages in a pluralistic sense.

My vision for the future is that CLIL, as a concept or as a term, won't even be used. This is blue sky thinking at the moment, but if we are looking at CLIL, not only as a simplistic way of merging language learning and content learning, but rather as a way of conceptualizing the role of language learning and language use within the school curriculum, then it immediately links with literacies, academic literacies, and text typologies, all of which are at the core of learning. 
Another fact is that in 2014, technology and financial changes are pushing individual societies of the Western world towards becoming much more pluralistic. Societies are changing and we are part of that change. The schooling system also has to change, but we all know that it is incredibly difficult for Education systems to change as quickly as society does; it takes time.

The authors: How do you think the 4Cs Framework (Content, Cognition, Communication and Culture) is going to evolve in a digital society where formal and non-formal education is currently emerging?

Do Coyle: In a way, the 4Cs is a conceptual tool which grew out of working with teachers and researchers, and is continuing to evolve. The 4Cs Framework integrates the different key elements which impact on CLIL. It is used in CLIL teachers' communities all over the world, now connected digitally, and makes me think that it is going to carry on evolving towards a more innovative and blended education model. To me, these connected communities can take all the theoretical ideas and use them to nourish education networks, but essentially what happens in the classroom is what matters. There are many different effective models of CLIL which operate in formal and non-formal education.

To a certain extent, it doesn't really matter how specific you want to be about the definitions of what each of the $4 \mathrm{Cs}$, because we know that learning is context related and essentially needs to be embeded in a socially interactive environment. Even now, when I look at some of the definitions of CLIL, I don't fully agree with those definitions, as we have moved on. The Four Cs Framework is a wake-up call and a reminder not to focus only on language, or only on content. If we just take the $\mathrm{C}$ for Cognition, which to me is for meaning-making, it embraces all the notions of understanding, and how children learn and negotiate meanings. If we go for the $\mathrm{C}$ for Culture, the one which is far away from the others in terms of development, we discover that it links to intercultural understanding, which could easily be related both to general societal cultures but specifically to learning cultures for example: literacies and collaborative problem solving. The aim of the 4Cs Framework is to enable people to say, "hang on, my lesson planning or curriculum planning is not enough." It is not about dealing with some subjects and adding the language, but to systematically integrate elements of learning which will lead to individual conceptual development and linguistic progression. 
The authors: Now we are including new strategies in class, such as Flipped Classrooms, BYOD (Bring Your Own Device) or Enquiring Minds. Considering the role of the teacher of CLIL in these environments, how would you summarize the evolution of foreign language teaching in Catalonia?

Do Coyle: In general, all the regions of Spain, including Catalonia, have been some of the leaders in developing classroom pedagogies in CLIL settings. English teachers in Catalonia have a huge knowledge base, which needs to be shared with subject teachers, so that together they will begin to share each other's expertise, and also grow something new. In my opinion, there is a lot of class-based research that needs to be done about what happens when you get subject experts and language experts working together in different classroom environments; what comes out of that, is really a shared understanding of language development and content learning.

Experimenting, reflecting and sharing with others are steps for professional development that every teacher should adopt. Technologies enable and encourage us to work together more collaboratively and to engage in professional learning across schools and regions- even across national boundaries. I would like to highlight that in the secondary sector, there is a tendency for us to become little islands within the school curriculum, whilst in the primary sector there is less of that tendency. What $\mathrm{I}$ am saying here is that the language teacher has a responsibility, just like all other teachers, to step outside of the 'comfort zone' and ask 'what exactly I am trying to teach in terms of languages; what is it that my learners need/want to do with language' and look more at the general learning agenda. Subject teachers also have a responsability to be more language aware and analyse carefully the language their learners need to learn effectively and deeply. By working together at school we can find more creative ways to improve the system a genuine 'bottom up' approach which will transform classroom practices.

The authors: That also brings us to 'Collaboration for Problem Solving', the new PISA proposal made by the OCDE for 2015. What do you think about it?

Do Coyle: Yes, I think this new OCDE approach for collaboration is very exciting. This has to be the way that we work, because according to some of Bruner's ideas, subjects should have no boundaries, they should be interlinked. If you look to universities now, you will 
discover that most of the research going on is not just individual research; it is all cross disciplinary. In a way, that echoes what eventually will need to happen in all education scenarios, and I truly believe that language teachers in Catalonia are well positioned both in terms of mind set and skill set to share expertise. It is always a privilege to work with them and I am always pleased to share ideas with them.

\section{Final words}

It's always a pleasure to hear about interlinked ideas and educational multi-scenarios from a university expert like Professor Coyle, now that higher education is in need of more creative propositions. Collaboration and international networking should be in the very bone of the university experience, both for students and teachers, if academic higher education wants to be meaningful for the global labour market. Cross-curricular strategies and connectivist transmedia approaches should be embedded in the general teaching and learning process at any level, even further than what traditional 4-Cs CLIL initially proposed. Blended learning, learning by doing and pre-service practicum training should be part of the usual teacher training experience, with opportunities to combine action-research and reflective-practice. Bridging the gap between theory and practice shouldn't be restricted to post-degree, life-long learning, but a naturally flowing process during university instructional learning, if we really believe in its values and potentialities for professional development.

More than that, rethinking CLIL in the Digital Age requires exploring its links to the virtual world, not only by searching for on-line school resources in different languages, but by creating open communities of interest, facilitating face-to-face meeting opportunities, sharing plurilingual and intercultural experiences, and making transmedia networking available to teachers and students, as essential components of the bridging process from university to the professional world.

The authors consider that these interviews with Prof. Do Coyle and Dr. Elisabet Pladevall, in the framework of a masters degree at the Universitat Autònoma de Barcelona, are examples of how traditional university events like a thesis defense can become opportunities for teacher training, round-table debates and shared conversations through public interviews in the transmedia universe of new CLIL research. 


\section{References}

Lorenzo, N., \& Gallon, R. (2015). Higher education and globalization. In F. M. Ribeiro, Y. Politis, \& B. Culum (Eds.) New voices in higher education research and scholarship (pp. 114-147). Hershey, USA: IGI Global.

Lorenzo, N. \& Piquer, I. (2013). Informe i valoració de l'evolució dels programes CLIL a Catalunya. Temps d'Educació, 45, 143-180.

Marsh, D. (1994). Bilingual education \& content and language integrated learning: Language teaching in the member states of the European Union (Lingua). University of Sorbonne, Paris: International Association for Cross-cultural Communication.

\footnotetext{
Author references:

Inma Piquer Vives is Lecturer at the Universitat de Barcelona (Catalonia, Spain) and at Blanquerna Universitat Ramon Llull. She currently works in the Servei de Llengües Estrangeres at the Departament d'Ensenyament (Generalitat de Catalunya).

Email: mpiquer3@xtec.cat (principal author)
}

Neus Lorenzo Galés is Inspector of Education in Barcelona (Catalonia, Spain). She is the former Head of the Servei de Llengües Estrangeres at the Departament d'Ensenyament (Generalitat de Catalunya) and the CoFounder of The Transformation Society in France.

To cite this article:

Piquer Vives, I., \& Lorenzo Galés, N. (2015). Reflecting on CLIL innovation. An interview with Do Coyle and Elisabet Pladevall. Bellaterra Journal of Teaching \& Learning Language \& Literature, 8(1), 86-93.

http://dx.doi.org/10.5565/rev/jtl3.610 